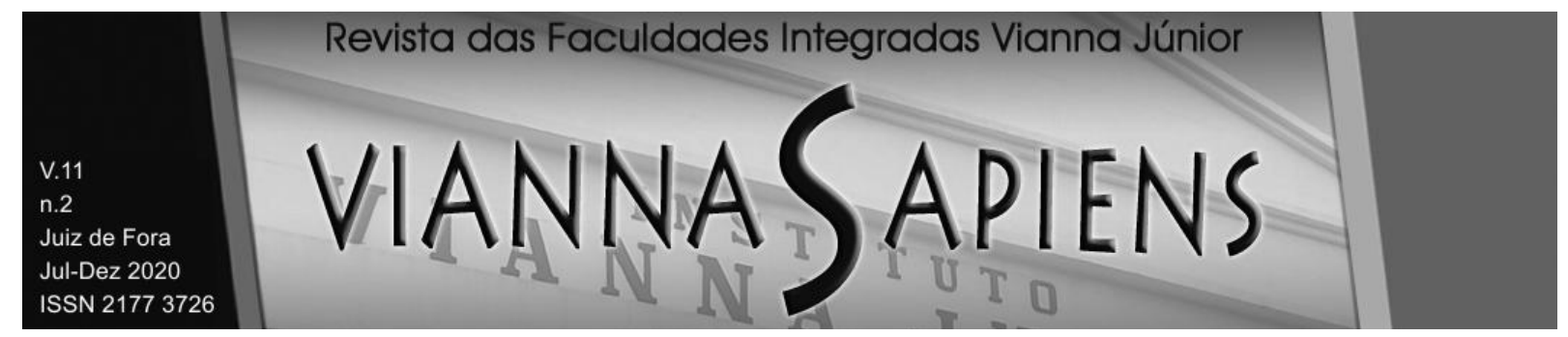

\title{
Reflexos do avanço expansionista à luz das velocidades do Direito Penal DOI: 10.31994/rvs.v11i2.692
}

\author{
Ramon Teixeira Turini ${ }^{1}$ \\ Bráulio da Silva Fernandes ${ }^{2}$ \\ Ricardo Ferraz Braida Lopes ${ }^{3}$
}

\section{RESUMO}

O trabalho tem seu enfoque voltado à uma análise sobre as implicações do fenômeno da Expansão Penal, sob a ótica da teoria inicialmente desenvolvida por Jesús-María Silva Sánchez, denominada "Velocidades do Direito Penal". O presente estudo tem como objetivo geral definir o modelo ideal para se alcançar a efetiva proteção do corpo social, a partir de uma observação crítica acerca do atual sistema punitivo do qual derivam as chamadas velocidades que, nesse contexto, têm figurado como o principal recurso para reagir às complexidades das causas pelas quais o Direito Penal se expande. Para tal, foi realizada pesquisa bibliográfica e documental, a partir de obras relacionadas ao tema. Entre as conclusões obtidas por meio deste trabalho, pode-se destacar que o descrédito das instâncias de proteção tem ressoado na formulação de novos ritmos de ação punitiva estatal, ora aqui denominados como velocidades do direito penal, resultando, por conseguinte, numa maior intensificação da resposta penal, em detrimento das liberdades individuais.

\footnotetext{
${ }^{1}$ Bacharel em direito pela Fundação Presidente Antônio Carlos; Pós-graduando em Ciências Penais pela Universidade Presidente Antônio Carlos; Advogado. E-mail: ramonturiniadv@gmail.com. Número de registro no ORCID: 0000-0003-4019-6020.

${ }^{2}$ Bacharel em direito pela Fundação Presidente Antônio Carlos; Mestrando em Teoria do Estado e Direito Constitucional pela Pontifícia Universidade Católica do Rio de Janeiro; pós-graduando em Ciências Penais pela Universidade Presidente Antônio Carlos; Advogado. E-mail: brauliosilvafernandes@gmail.com. Número do registro no ORCID: 0000-0002-2730-7876.

${ }^{3}$ Docente no curso de direito da FUPAC-UBÁ e da Estácio de Sá de Juiz de Fora. Possui Mestrado em Estudos Literários pela UFJF e, atualmente, doutorando em sociologia e direito pela UFF. E-mail: ricardofbraida@gmail.com. Número de registro no ORCID: 0000-0002-0951-3668.
} 


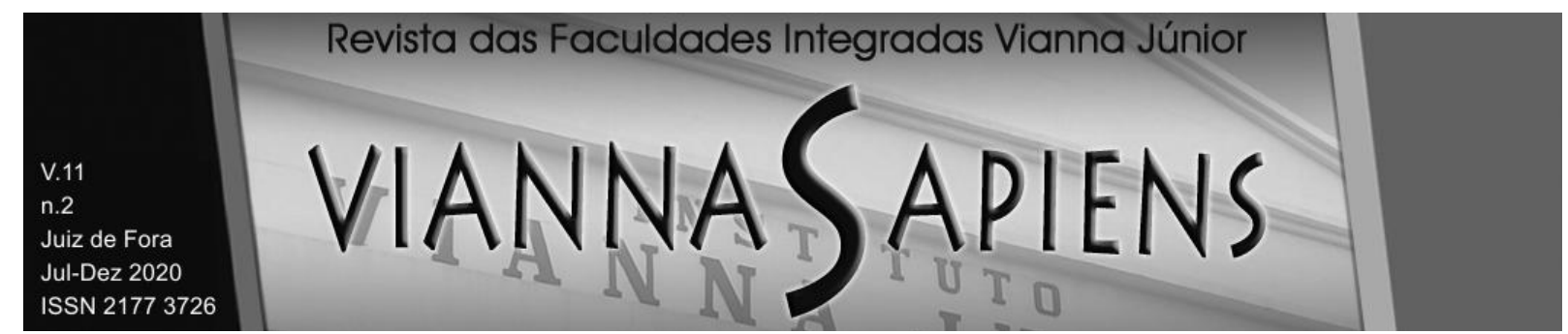

Por fim, salienta-se que o artigo tem a pretensão de conceder ao leitor, em especial, uma visão crítica do tema, explorando pertinentes pontos acerca do objeto em análise.

PALAVRAS-CHAVE: EXPANSÃO. VELOCIDADES. SOCIEDADE. RISCO. FUNCIONALISMO.

\title{
Reflections of the expansionist advance in the light of the speeds of Criminal
}

Law

\begin{abstract}
The work focuses on an analysis of the implications of the phenomenon of Penal Expansion, from the perspective of the theory initially developed by Jesús-María Silva Sánchez, called "Speeds of Criminal Law". The present study has the general objective of defining the ideal model to achieve the effective protection of the social body, based on a critical observation about the current punitive system from which the so-called speeds derive, which, in this context, have been the main resource for react to the complexities of the causes by which Criminal Law expands. To this end, bibliographical and documentary research was carried out, based on works related to the theme. Among the conclusions obtained through this work, it can be highlighted that the discrediting of the instances of protection has resonated in the formulation of new rhythms of state punitive action, now referred to as penal law speeds, resulting, therefore, in a greater intensification of criminal response, to the detriment of individual freedoms. Finally, it is emphasized that the article intends to grant the reader, in particular, a critical view of the theme, exploring pertinent points about the object under analysis.
\end{abstract}




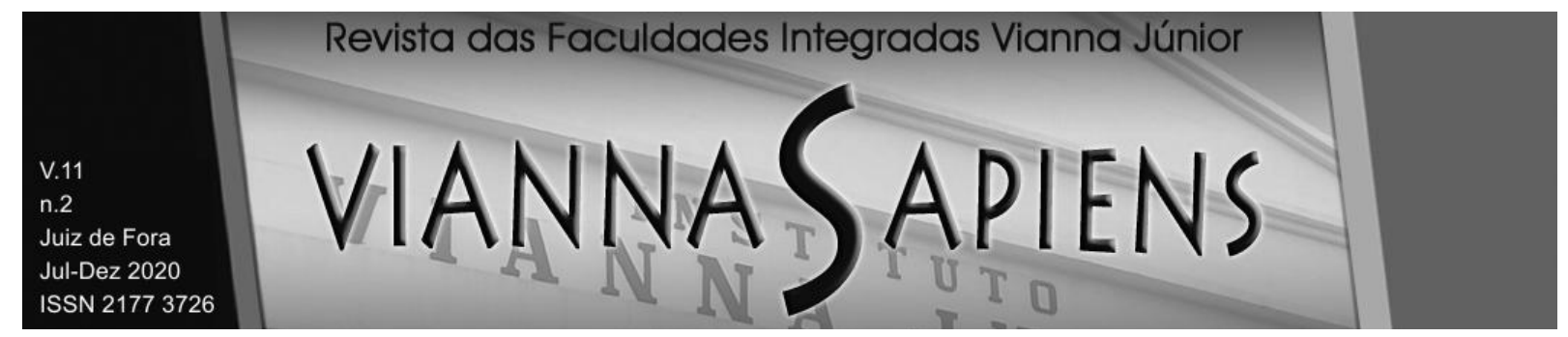

\section{KEYWORDS: EXPANSION. SPEEDS. SOCIETY. RISK. FUNCTIONALISM.}

\section{INTRODUÇÃO}

A expansão penal tem figurado como questão central de recentes reflexões político-criminais, com conjecturas que remetem a pressupostos preventivos contra os novos riscos dispostos na sociedade moderna. Nessa conjuntura, os novos paradigmas da sociedade atualmente vêm sendo moldados sob grande influxo da comunicação instantânea. Hoje, um crime cometido em um determinado estado é noticiado em outro, separados por milhares de quilômetros de distância, instantaneamente, a ponto de causar uma percepção inexata acerca daquilo que está perto e o que está distante.

Tendo por base o crescente avanço tecnológico no Brasil, o curso dos acontecimentos somados à rapidez de sua comunicação se tornaram bastantes para reforçar a sensação de insegurança jurídica e transformarem suas questões cruciais na ideia de repressão imediata, mesmo desconhecendo "quem eles são" e "como estão fazendo". Nessa perspectiva, o controle contínuo e a comunicação instantânea, aqui, passam a ser a estratégia principal do exercício do poder frente aos novos "riscos" existentes. O olho que vigia e pune, hoje, é o mesmo que relega, em pleno Estado Democrático de Direito, as garantias individuais do cidadão.

Nesse aspecto, a partir das profundas alterações exigidas para se alcançar um efetivo instrumento para gestão dos problemas sociais no cenário jurídico atual, tem-se percebido que a criminalidade vem se adequando facilmente às novas estratégias de controle social decorrentes desse novo formato do Direito Penal, culminando na formulação de novas tendências punitivistas tachadas como "velocidades do direito penal", que, por seu turno, consagram diferentes ritmos de ação punitiva estatal.

Dentro desse fenômeno, ante o sentimento de insegurança que surge no cenário da sociedade, o Estado passa a exercer um papel manifestamente 


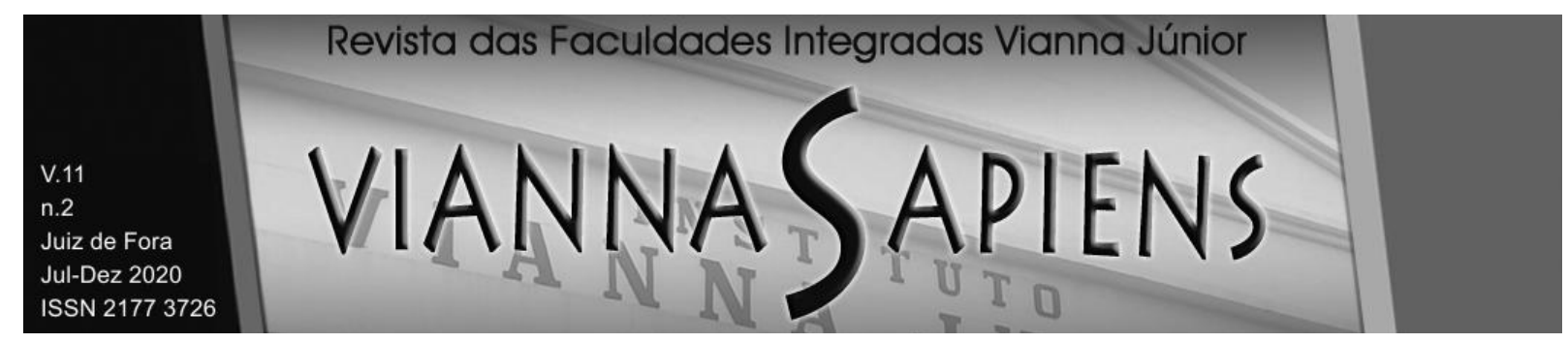

controlador e fiscalizador, através do qual se enxerga uma gradativa extenuação da função garantidora dos limites e condições de justificação da proibição penal.

A despeito disso, surgiu a seguinte problemática: seria adequado o Direito Penal se alinhar, estritamente, a um modelo criminalizador, com o propósito de restaurar o equilíbrio social, mediante a formulação de novas tendências punitivistas, em sacrifício do sistema de direitos e garantias fundamentais?

Assim, resta claro que o presente trabalho tem como objetivo definir o modelo ideal para se alcançar a efetiva proteção do corpo social, a partir de uma análise crítica acerca do atual sistema punitivo, do qual derivam as chamadas velocidades que, nesse contexto, têm figurado como o principal recurso para reagir às complexidades das causas pelas quais o Direito Penal se expande.

Para tal, salienta-se que foi realizada pesquisa bibliográfica e documental, a partir de obras relacionadas à temática abordada.

No primeiro tópico, para alcançar a conclusão proposta, far-se-á uma análise da teoria proposta por Jesús-María Silva Sánchez, onde serão analisados diferentes direitos penais coexistentes, a partir de uma exposição sumária acerca do sistema do "Direito Penal de Duas Velocidades" e, ainda, o chamado "Direito Penal do Inimigo".

No que se refere ao segundo tópico, a análise fica a cargo da elucidação das novas vertentes doutrinárias que culminaram na formulação de novas tendências punitivistas tachadas como Velocidades do Direito Penal, além de enfatizar uma nova fase vivida pelo Direito Penal, em decorrência de seu próprio estilo expansivo.

Por fim, o terceiro capítulo tem por objetivo contribuir com a produção intelectual sobre o tema, proporcionando ao leitor uma visão crítica no que tange ao atual sistema punitivo, onde se discorre acerca das tendências de direito penal para o futuro e uma espécie de "fetichismo" pelas velocidades, buscando elucidar as consequências projetadas por um modelo criminalizador corolário de uma exacerbada preocupação prevencionista, onde o Direito Penal se apresenta como (única) solução para os problemas sociais. Nesse ponto, o estudo se desenvolve, ainda, a partir de uma contextualização do que se denomina Sociedade do Risco, 


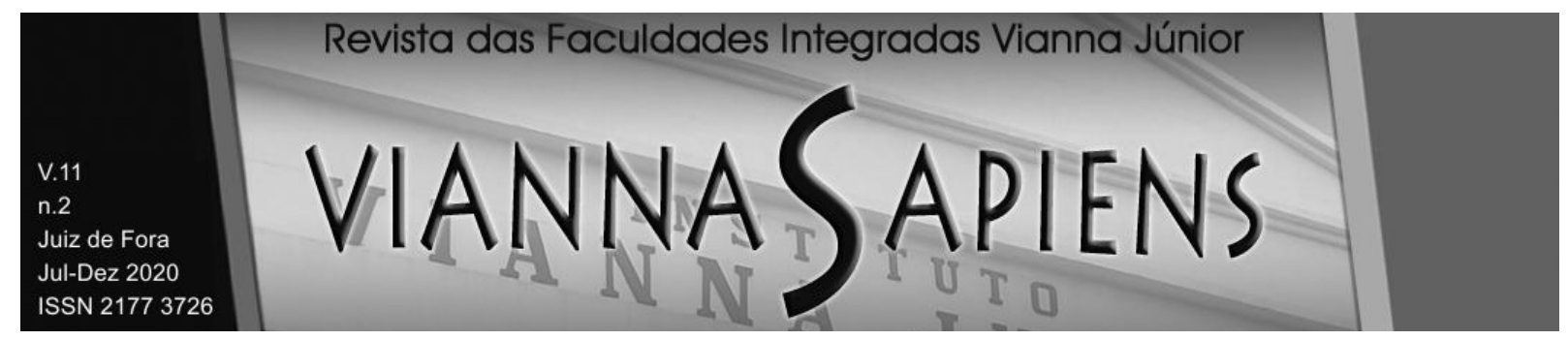

tendo em vista que a crescente demanda social por uma resposta penal imediata e eficaz constitui um dos aspectos principais que conduzem ao recrudescimento do aparato repressivo do Estado.

Em síntese, a pretensão do estudo é levar o leitor a uma análise crítica acerca das ciências que procuram explorar o fenômeno abordado, além de demonstrar as disfunções de uma atuação impetuosa do Estado, que se vê, cada vez mais, se desvencilhando de sua característica de democrático de direito.

\section{AS VELOCIDADES DO DIREITO PENAL DE JESÚS-MARIA SILVA SÁNCHEZ}

O Direito Penal constitui-se um importante mecanismo com vistas à proteção de bens jurídicos de maior envergadura no seio social. Sendo assim, na medida em que surgem novos bens jurídicos a serem tutelados, nasce do outro lado a necessidade de expansão desse instrumento, com o intuito de promover sua efetiva proteção por meio da introdução e aplicação de novas normas penais com maior vigor.

Com o desenvolvimento e as mudanças sociais que emergem da dinâmica e da complexidade dos homens, surge a expansão e a intensificação da resposta penal diante dos novos problemas sociais, dando azo à modernização caracterizada pela flexibilização dos princípios político-criminais e regras de imputação. Nesse sentido, o avanço expansionista, fruto de uma nova sociedade moldada pelas transformações ocorridas no Direito Penal, exige um novo arsenal instrumental para o enfrentamento da criminalidade moderna. Assim, para solucionar esse dilema, a doutrina tem sugerido uma nova orientação para a análise do Direito Penal, batizada entre os especialistas como "Velocidades do Direito Penal".

As primeiras noções sobre as velocidades do direito penal foram concebidas pelo professor espanhol Jesús-María Silva Sánchez em sua obra "A Expansão do 


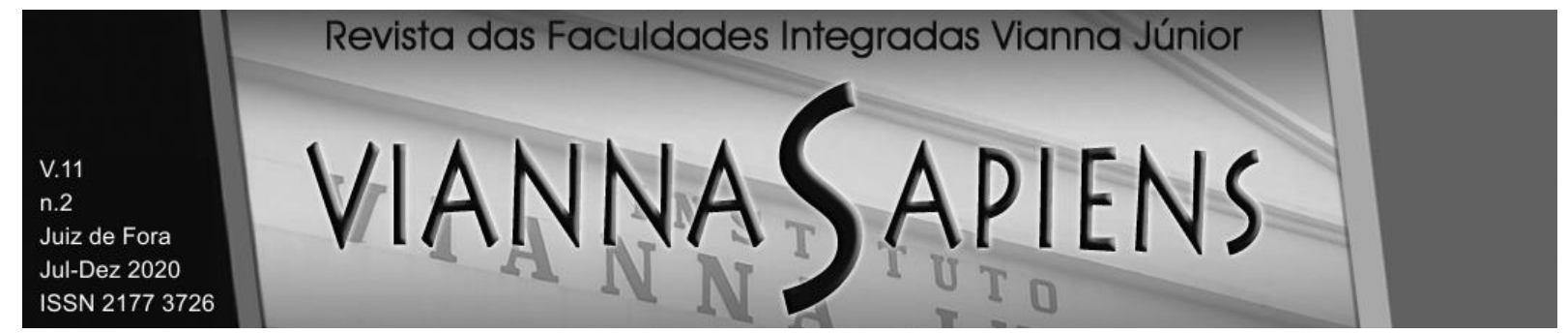

Direito Penal: Aspectos da política criminal nas sociedades pós-industriais"4, para descrever os problemas da expansão do Direito Penal moderno. As bases pelas quais se denominam "velocidades" guardam relação com o tempo que o Estado leva para punir o autor de uma infração penal, contemplando diferentes direitos penais coexistentes, aplicáveis a situações diversas. Com efeito, a noção de velocidades proposta por Silva Sánchez abarca diferentes ritmos de responsabilização criminal conforme a gravidade do delito, visando alcançar um sistema mais próximo do ideal.

\subsection{Direito Penal de duas velocidades}

Invocando-se os ensinamentos de Sánchez (2013), tem-se, inicialmente, que o Direito Penal, no bojo de sua unidade substancial, divide-se em dois grandes blocos distintos de ilícitos: o primeiro das infrações penais cominadas com penas de prisão e, o segundo, daquelas que se vinculam aos gêneros diversos de sanções penais. Trata-se, pois, de um modelo dualista de sistema penal, denominado de Direito Penal de duas velocidades.

Conhecido também como Direito Penal da Prisão ${ }^{5}$, o Direito Penal de primeira velocidade está relacionado com as infrações penais que invariavelmente resultam na imposição de pena privativa de liberdade. Cuida-se de um modelo liberal-clássico fundado em garantias individuais inarredáveis, visto que, por envolver a liberdade do ser humano, exige-se um procedimento extremamente garantista. Consequentemente, nesse nível de intensidade haverá um procedimento mais demorado, com observância de todas as garantias penais e processuais penais, além dos critérios clássicos de imputação.

Já o Direito Penal de segunda velocidade trabalha com as infrações penais que têm como consequência jurídica a aplicação de penas alternativas (penas

\footnotetext{
${ }^{4}$ Título original: "La expansión del derecho penal: aspectos de la política criminal em las sociedades postindustrialies".

${ }^{5}$ Não se deve confundir Direito Penal da Prisão com Direito Penal da Pena Privativa de Liberdade, uma vez que todos os crimes, com exceção do art. 28 da Lei n. $-11.343 / 06$, preveem pena privativa de liberdade (Reclusão ou Detenção). Assim, quando se fala em Direito Penal da Prisão, trata-se dos poucos crimes que inevitavelmente levam o agente à perda da liberdade.
} 


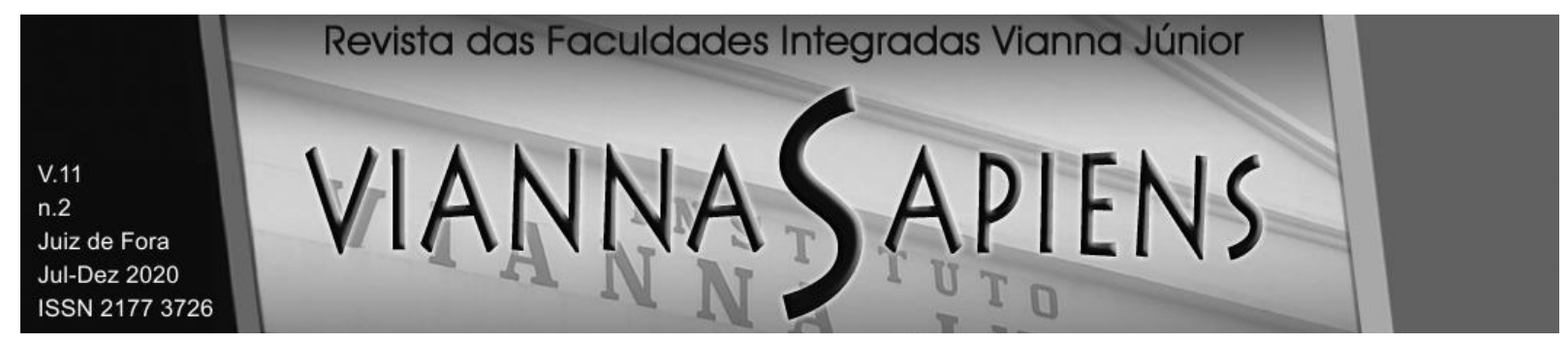

restritivas de direito ou de multa). Parte do pressuposto de que, por não envolver bens jurídicos de maior projeção na disputa entre o Estado e o acusado, sobretudo a liberdade do ser humano, deve-se admitir uma flexibilização proporcional de direitos e garantias fundamentais, possibilitando uma punição mais rápida do agente. Temse, portanto, um procedimento mais célere, caracterizado pela relativização de determinadas garantias penais e processuais penais aliada à adoção de medidas alternativas à prisão. ${ }^{6}$

Nessa mesma linha, nas lições de Sánchez (2013, p. 193):

Uma primeira velocidade, representada pelo Direito Penal "da prisão", na qual haver-se-iam de manter rigidamente os princípios político-criminais clássicos, as regras de imputação e os princípios processuais; e uma segunda velocidade, para os casos em que, por não se tratar já de prisão, senão de penas de privação de direitos ou pecuniárias, aqueles princípios e regras poderiam experimentar uma flexibilização proporcional à menor intensidade da sanção.

A grosso modo, as velocidades têm sua característica de atuação pautada pela gravidade da infração penal. É se observar que na segunda velocidade ocorre uma flexibilização proporcional à intensidade da sanção imposta. Assim, com a flexibilização das garantias e dos princípios processuais, haver-se-á a exclusão da pena de prisão. Contudo, vale anotar que tal característica se perde na chamada $3^{\underline{a}}$ (terceira) velocidade, na qual, malgrado tratar-se de um procedimento flexibilizado, se visa unicamente a aplicação de penas privativas de liberdade, conforme será analisado a seguir.

\footnotetext{
${ }^{6}$ Toma-se como exemplo a Lei n. .9 9.099/95 (Lei dos Juizados Especiais), que prevê o instituto da Transação Penal (art. 76) bem como a Suspensão Condicional do Processo (art. 89), ocorrendo a flexibilização de determinadas garantias, tais como devido processo legal, contraditório e ampla defesa, com a implementação do procedimento sumaríssimo para as infrações consideradas de menor potencial ofensivo e possibilidade de imposição de medidas alternativas à prisão antes mesmo do oferecimento da denúncia.
} 


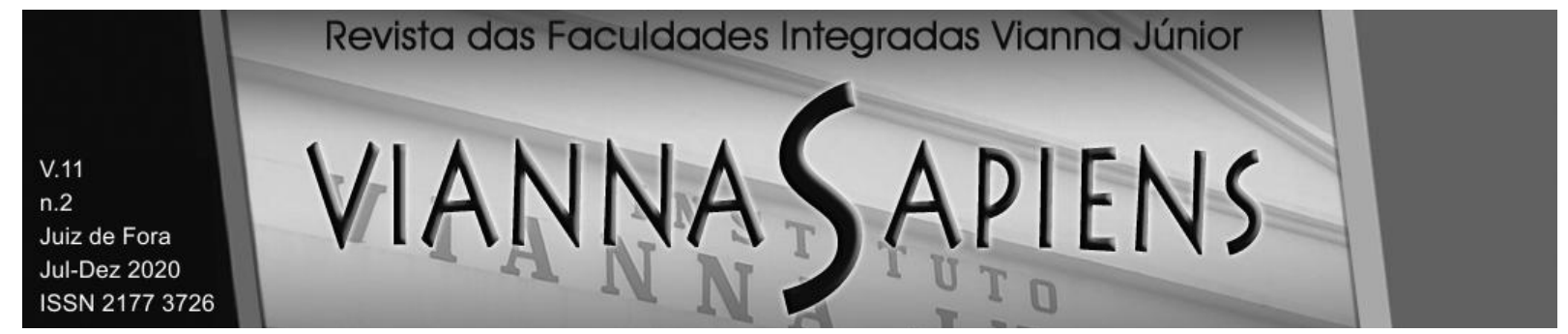

\subsection{Terceira velocidade e o Direito Penal do inimigo}

Tecidas tais considerações acerca do sistema dualista inicialmente proposto por Jesús-María Silva Sánchez, onde se desenvolvem as duas velocidades anteriores, indaga-se sobre a existência de uma 'terceira velocidade', na qual "[...] o Direito Penal da pena de prisão concorra com uma ampla relativização de garantias político-criminais, regras de imputação e critérios processuais" (SÁNCHEZ, 2013, p. 193). A respeito do assunto, Sánchez (2013, p. 193), em sua obra denominada $A$ Expansão do Direito Penal, assevera que:

\footnotetext{
Sem negar que a "terceira velocidade" do Direito Penal descreve um âmbito que se deveria aspirar a reduzir a mínima expressão, aqui se acolherá com reservas a opinião de que a existência de um espaço de Direito Penal de privação de liberdade com regras de imputação e processuais menos estritas que as do Direito Penal da primeira velocidade, com certeza, é, em alguns âmbitos excepcionais, e por tempo limitado, inevitável.
}

O direito penal de terceira velocidade refere-se, portanto, a uma mescla entre as características atinentes às velocidades anteriores. Consequentemente, há a utilização da pena privativa de liberdade (típico da $1^{\underline{a}}$ velocidade) com a flexibilização de garantias penais e processuais penais (como ocorre na $2^{\mathrm{a}}$ velocidade).

Essa questão guarda uma estreita relação com o Direito Penal do Inimigo, teoria desenvolvida pelo catedrático professor alemão Günther Jakobs. Para Jakobs (2005), entende-se como inimigo o indivíduo que, tido como infiel ao próprio sistema, afronta diretamente a estrutura do Estado ao assumir, de forma duradoura, um modo de vida contrário às expectativas normativas. Logo, sendo o criminoso desconexo com sua função no corpo social, dá-se de forma contínua a perda do status de cidadão - sujeito de direitos - passando o mesmo a ser combatido como inimigo do estado.

Ademais, Sánchez (2013) assevera que a transição do "cidadão" ao "inimigo" ocorrerá através da reincidência, a habitualidade, a delinquência profissional e, por fim, a integração em organizações delitivas estruturadas. 


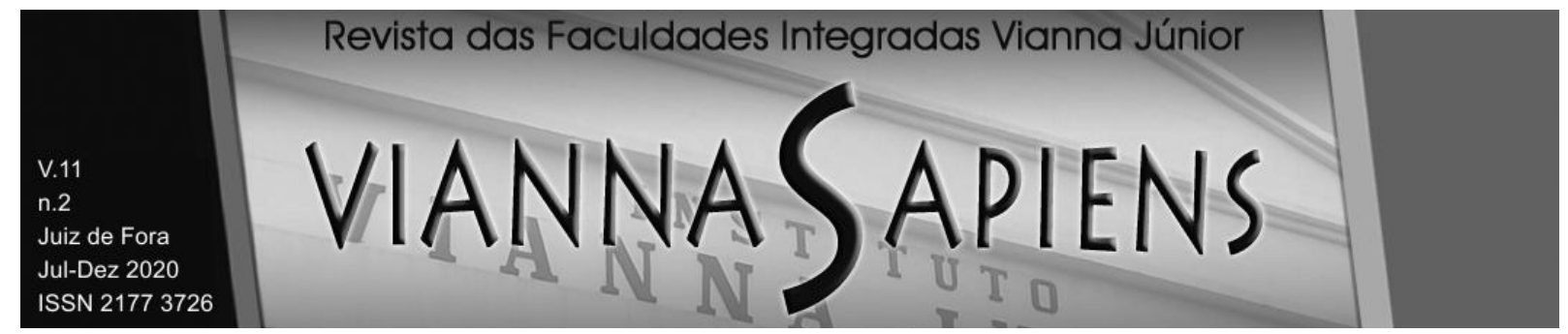

Neste viés, Masson (2017, p. 116), ao discorrer objetivamente sobre o tema, salienta que:

Nitidamente, enxerga-se na concepção de Jakobs a convivência de dois direitos em um mesmo ordenamento jurídico. Em primeiro lugar, um direito penal do cidadão, amplo e dotado de todas as garantias constitucionais, processuais e penais, típico de um Estado Democrático de Direito. Sem prejuízo, em parcela menor e restrita a grupos determinados, com ele coexiste o Direito Penal do inimigo, no qual o seu sujeito deve ser enfrentado como fonte de perigo e, portanto, a sua eliminação da sociedade é o fim último do Estado.

É nesse contexto que Silva Sánchez define o Direito Penal do Inimigo como sendo a terceira velocidade do Direito Penal. Vislumbra-se, neste modelo, o Estado respondendo de forma mais intensa e mais célere diante da prática de determinados crimes tidos como de maior gravidade. Em contrapartida, não se pode olvidar que o direito penal de terceira velocidade consubstancia-se através de um Direito Penal de Emergência, devendo, portanto, ser concebido como um instrumento de abordagem de fatos de urgência fomentados pelas situações em que se faz presente a sensação de insegurança na sociedade, como, por exemplo, os atos de Terrorismo.

Noutro giro, cumpre registrar que Jakobs também é responsável pela premissa de que a aplicação constante da norma é o que imprime maior garantia de validade do sistema, conhecida como funcionalismo radical, monista ou sistêmico, cuja concepção se coaduna com o Direito Penal do Inimigo, o qual se verifica como a terceira velocidade do direito penal, colocando em discussão a real efetividade do Direito Penal.

\subsubsection{Funcionalismo Penal}

Conhecido também como pós-finalismo, o movimento doutrinário concebido como Funcionalismo Penal surgiu na Alemanha, na década de 70, buscando, em apertada síntese, compreender a real função que o Direito Penal pode desenvolver na sociedade. As teorias funcionalistas nascem da percepção de que o Direito Penal 


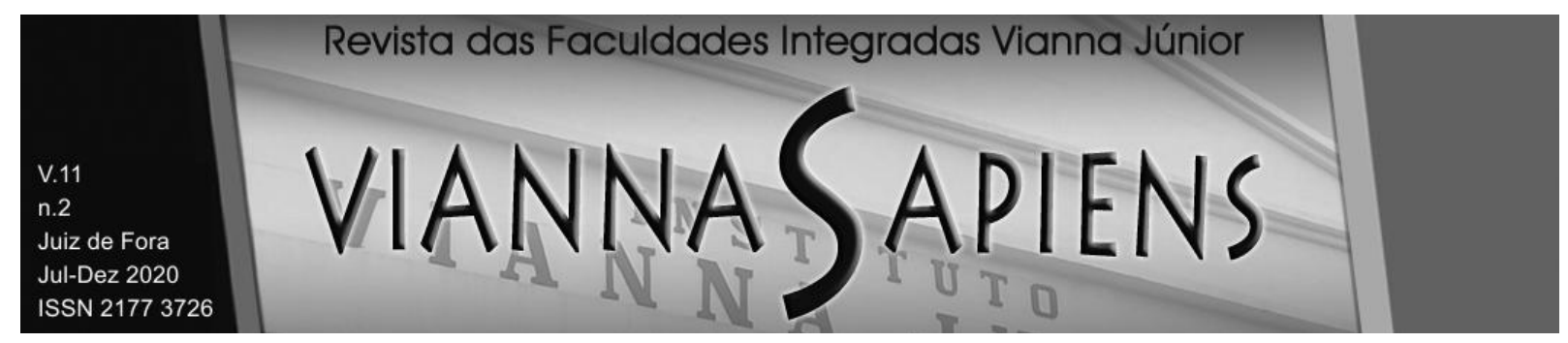

materializa-se a partir da missão que lhe é conferida, de sorte que seus institutos devem orientar-se exclusivamente pelos seus fins. Vislumbra-se, pois, o Direito Penal como uma função inserida na ordem jurídica.

Nessa esteira, são duas as principais modalidades do funcionalismo penal que disputam primazia entre si: o Funcionalismo Teleológico, Dualista, Moderado ou de Política Criminal e o Funcionalismo Radical, Sistêmico ou Monista.

A primeira vertente tem como expoente Claus Roxin, cuja concepção é marcada pela inserção de critérios político-criminais no âmbito do sistema jurídicopenal. Com efeito, para a referida corrente, a preocupação precípua do direito penal relaciona-se com a proteção de bens jurídicos, sendo mais aceitável sua aplicação.

Já a orientação funcionalista capitaneada por Günther Jakobs, denominada de funcionalismo radical, sistêmico ou monista, parte da premissa de que a função do Direito Penal consiste em assegurar o império da norma. Tem-se, portanto, o delito como frustração das expectativas normativas e a pena como a confirmação da norma violada.

Nesse diapasão, segundo Cunha (2016), sob a ótica do funcionalismo de Jakobs, tem-se um sistema penal cuja preocupação encontra-se pautada na higidez das normas estabelecidas para regular as relações sociais. Por conseguinte, a aplicação constante da norma se faz necessária para imprimir à sociedade os comportamentos indesejados e as condutas conexas com o sistema normativo e os fatores de proteção social.

De outro bordo, vale ressaltar que o funcionalismo de Roxin diz-se moderado na medida em que se admite a submissão do Direito Penal aos limites exteriores ao seu próprio sistema. Nessa mesma linha, parte-se do pressuposto de que a dogmática penal deve ser direcionada a uma finalidade protetiva dos bens jurídicos imprescindíveis ao desenvolvimento social, cuja seleção terá como norte a própria Constituição Federal, segundo a concepção garantista do Direito Penal, a fim de evitar a imposição de determinados comportamentos violadores de direitos fundamentais atribuídos a toda pessoa humana. 


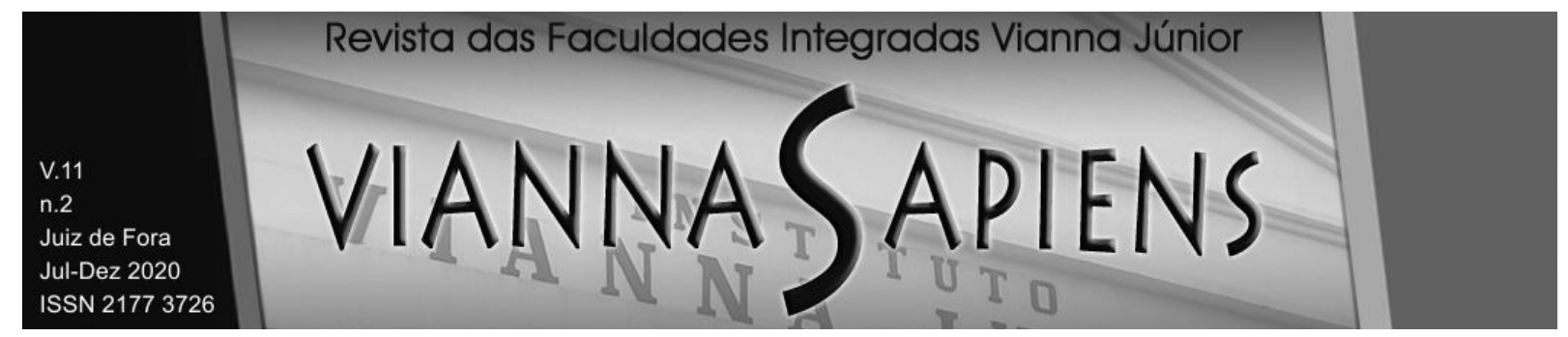

Na concepção de Jakobs propõe-se, através de um funcionalismo monista, um sistema penal autopoiético, visto que neste não seria possível se admitir a ingerência de fatores externos. Dessa forma, nesta orientação funcionalista o Direito Penal não encontra limites externos, mas tão somente internos.

É nessa última corrente, aliás, que se encontra relação com o chamado Direito Penal de terceira velocidade, onde também se expande o Direito Penal do Inimigo, eis que, ao direcionar-se exclusivamente à reafirmação da norma violada, tem-se um sistema que ignora os direitos e garantias fundamentais esparsos pelo ordenamento jurídico. Nesse contexto, Cunha (2016, p. 188) ressalta que:

As premissas sobre as quais se funda o funcionalismo sistêmico deram ensejo à exumação da teoria do Direito Penal do Inimigo, representando a construção de um sistema próprio para o tratamento do indivíduo considerado "infiel ao sistema". Considera que àquele que se dedica a determinados crimes não se deve garantir o status de cidadão, merecendo, ao revés, punição específica e severa, uma vez que o seu comportamento põe em risco, de forma ímpar, a integridade do sistema. (Grifo nosso)

Dessarte, em uma análise sistemática sob o prisma das velocidades do direito penal, é de se notar que o Direito Penal de terceira velocidade tem guarida na teoria funcionalista de Jakobs, dado que o indivíduo tido como "inimigo do Estado" que pratica crimes de alta periculosidade, infringido a norma, está sujeito a uma pena mais rígida cumulada com a relativização de garantias penais e processuais penais ${ }^{7}$, para o fim de assegurar a vigência e intangibilidade da norma penal.

\footnotetext{
${ }^{7}$ Este modelo de sistema penal tem sido objeto de diversas críticas na doutrina. Nesse seguimento, considera-se que a partir do momento em que o Estado passa a responsabilizar alguém, diminuindoIhe as oportunidades de provar sua inocência, a probabilidade de se condenar de forma rígida pessoas inocentes passa a ser muito mais ampla. Por essa razão, não se sugere aplicação da $3^{\text {a }}$ (terceira) velocidade no cenário atual, visto que representa uma verdadeira afronta aos princípios e garantias do Estado de Direito e patente injustiça jurídico-penal.
} 


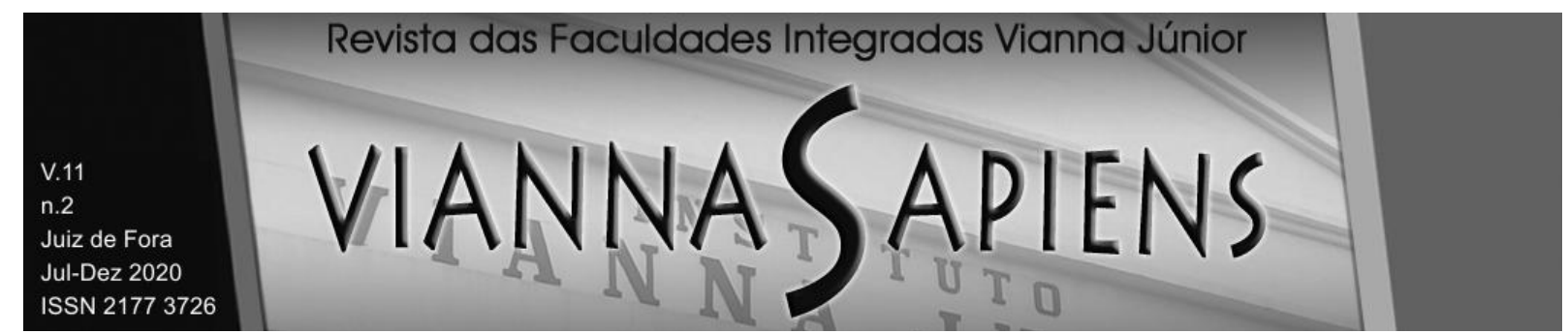

\section{NOVAS TENDÊNCIAS DOUTRINÁRIAS SOBRE AS VELOCIDADES DO DIREITO PENAL}

A expansão penal tem repercutido hodiernamente na manifestação de novas tendências doutrinárias que atinam às chamadas 'velocidades do Direito Penal', gerando novas discussões e debates na seara criminal. Conforme elucidado, a teoria das velocidades foi desenvolvida inicialmente pelo professor espanhol, JesúsMaría Silva Sánchez, responsável pela noção de que o Direito Penal se desenvolveria, a priori, em duas velocidades, consagrando-se, ainda nesta sequência, o chamado "direito penal do inimigo", rotulado como a $3^{\text {a }}$ (terceira) velocidade.

A partir dessa linha de sistematização do direito penal contemporâneo, caracterizado pelo seu próprio estilo expansivo, nasce uma nova fase vivida pelo Direito Penal, cujas transformações vêm recebendo um importante tratamento conferido pela doutrina moderna. Com efeito, atualmente se vislumbra o surgimento de novos ritmos de ação punitiva estatal, através dos quais se consagram o Direito Penal de quarta e quinta velocidades.

\subsection{Direito Penal de quarta velocidade (Neopunitivismo)}

Recentemente, estudiosos têm anunciado um Direito Penal de quarta velocidade, através do qual se inspira o chamado "direito penal dos direitos humanos" ou "Neopunitivismo", termos concebidos pelo professor argentino, Daniel Roberto Pastor, em sua obra: "La deriva neopunitivista de organismos y activistas como causa dei desprestigio actual de los derechos humanos" ${ }^{\text {". }}$. Trata-se de um sistema inserido no âmbito da jurisdição penal internacional voltado à proteção de bens jurídicos universais ou transnacionais, aplicável em face daqueles que uma vez

\footnotetext{
8 Tradução do Título: "A tendência neopunitivista dos organismos e ativistas como causa do desprestígio atual dos direitos humanos".
} 


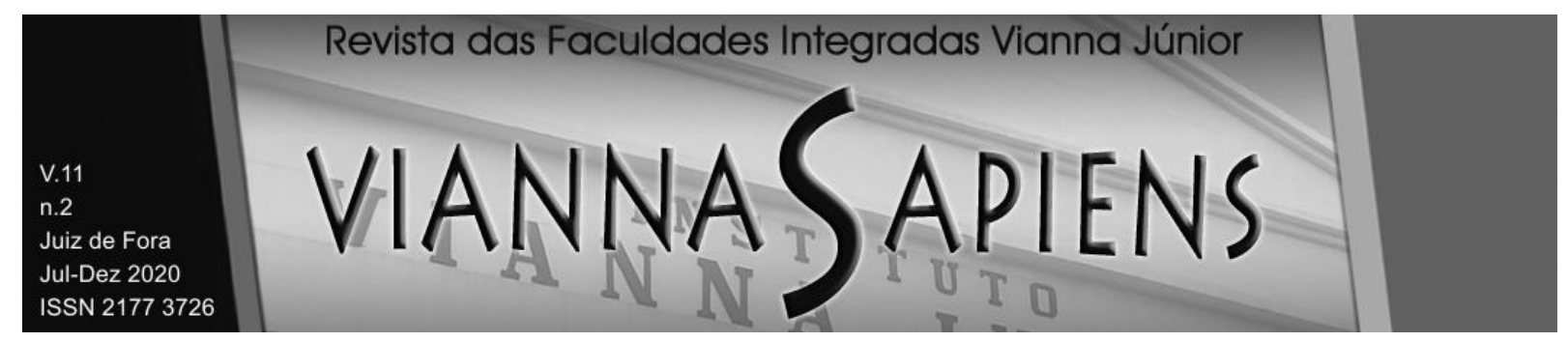

ostentaram a posição de chefes de Estado e, como tais, violaram gravemente tratados internacionais de tutela de Direitos Humanos.

Pode-se afirmar que a quarta velocidade se conecta ao plano do Direito Penal Internacional $^{9}$, com a incidência de normas externas tendentes a uma maior diminuição ou supressão de garantias materiais e processuais do acusado ${ }^{10}$. Isso porque, ao se afastar ainda mais do modelo Liberal-Clássico, ter-se-á uma ampla redução das garantias individuais, consoante explica Pastor (2015, p. 76):

Igualmente, decorrem do neopunitivismo manifestações restritivas dos direitos fundamentais em matéria de acusação. Aqui se produz, como consequência do fenômeno disfuncional mencionado, uma afetação dos fundamentos axiológicos da jurisdição penal, em geral justificados tão somente através de simples critérios de eficiência e de combate à criminalidade. Assim, sob o pretexto de se alcançar a eficiência na persecução e punição dos delitos e ante a enorme quantidade de processos que inevitavelmente gera o neopunitivismo com sua política criminal inflacionária, tem-se recorrido a instrumentos inconstitucionais que derrogam os valores que, inevitavelmente, devem ser respeitados pelo sistema penal de um Estado constitucional de direito. (Tradução nossa ${ }^{11}$ )

\footnotetext{
${ }^{9} \mathrm{Na}$ história, cita-se como exemplo os Tribunais Militares Internacionais formados na cidade de Nuremberg, na Alemanha, entre os anos de 1945 a 1949, para apurar e julgar os crimes nazistas praticados durante a Segunda Guerra Mundial, os quais ficaram conhecidos como "Julgamento de Nuremberg", onde é possível vislumbrar o Direito Penal de 4⿳亠丷厂 (quarta) Velocidade. Essa velocidade também pode ser observada através de outros Tribunais Internacionais ad hoc, como o Tribunal Penal Internacional para a Ex-lugoslávia (TPII), criado para responsabilizar e julgar os indivíduos por crimes de guerra cometidos no território da antiga lugoslávia.

${ }^{10}$ A exemplo, a ampla defesa bem como o direito de constituir defensor, tendo em vista que, sendo o inimigo concebido como uma ameaça à ordem pública, desconsidera-se sua posição de sujeito na relação jurídico-processual, operando-se, por conseguinte, uma defesa meramente formal. Ademais, há nítida violação às regras básicas do poder punitivo, tal como ocorre com o princípio do juiz natural, na medida em que se possibilita a constituição de tribunais ad hoc, e também do próprio sistema acusatório.

11 "Igualmente provienen del neopunitivismo manifestaciones restrictivas de los derechos fundamentales en el ámbito del enjuiciamiento. Aquí se produce, como consecuencia del fenómeno disfuncional señalado, una afectación de los fundamentos axiológicos de la jurisdicción penal, en general justificada únicamente en simples criterios de eficiencia y lucha contra el crimen. Así pues, bajo la invocación de lograr eficacia en la persecución y el castigo de los delitos y ante la enorme cantidad de procesos que inevitablemente genera el neopunitivismo con su política criminal inflacionaria, se ha recurrido a instrumentos inconstitucionales que derogan los valores que insoslayablemente deben ser respetados por el sistema penal de un Estado constitucional de derecho."
} 


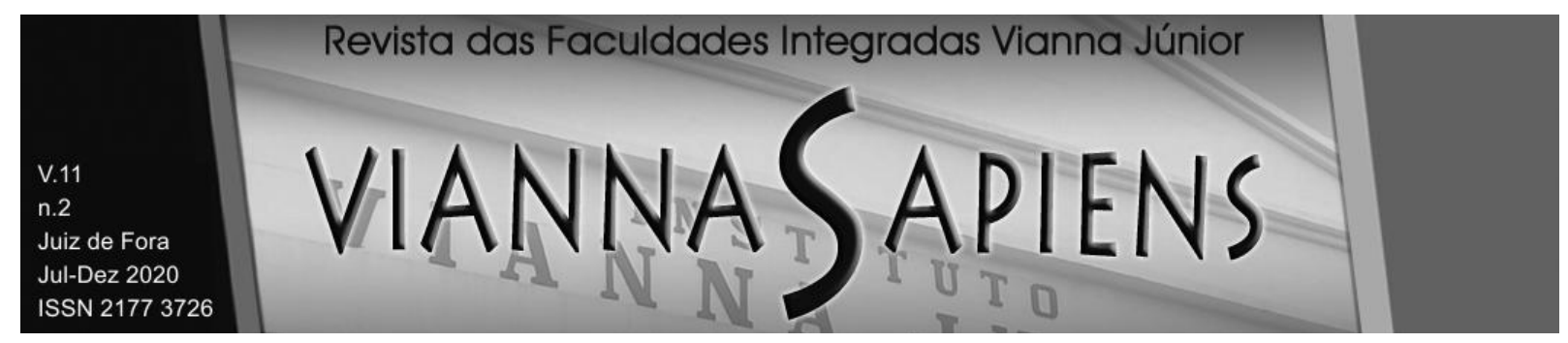

O primeiro diploma legal de caráter e incidência internacional surgiu na Itália em 17 de Julho de 1998, denominado "Estatuto de Roma", responsável por instituir a Corte Penal Internacional, mais conhecida no Brasil como Tribunal Penal Internacional (TPI), por meio do qual se materializa a quarta velocidade do direito penal. O Brasil passou a ser signatário do referido tratado em 2002, quando o Congresso Nacional aprovou o Estatuto através do Decreto Legislativo n.ำ 112, sendo mais tarde promulgado pelo Decreto n.. 4.388/02. Nesse sentido, o Brasil, assim como outros países signatários, se submete à jurisdição do Tribunal Penal Internacional, conforme se extrai da redação do parágrafo $4^{\circ}$ contido no artigo $5^{\circ}$ da Carta Constitucional ${ }^{12}$, incluído com o advento da Emenda Constitucional n.. $45 / 2004 .^{13}$

Sediado em Haia, na Holanda, o Tribunal possui competência para o processo e julgamento dos crimes de genocídio, crimes contra a humanidade, crimes de guerra e crimes de agressão ${ }^{14}$, desde que previstos no respectivo Estatuto, objetivando a promoção do Direito Internacional e a Universalidade dos Direitos Humanos. Não obstante, vale frisar que a competência do Tribunal Penal Internacional é subsidiária, possuindo caráter de complementariedade, sendo competente para o julgamento somente nos casos em que houver omissão ou incapacidade por parte do Estado de origem do criminoso para puni-lo pelo crime praticado no respectivo território. ${ }^{15}$ Deste modo, permanece com os entes nacionais a competência primária para processar e julgar os crimes cometidos sob sua jurisdição.

\footnotetext{
${ }^{12}$ In verbis: "O Brasil se submete à jurisdição de Tribunal Penal Internacional a cuja criação tenha manifestado adesão".

${ }_{13}$ Considerando que o Estatuto de Roma se incorporou ao ordenamento jurídico brasileiro em momento anterior ao advento da Emenda Constitucional n.․ 45/2004, razão pela qual não foi submetido ao quorum qualificado (três quintos em dupla votação em cada casa do Congresso Nacional), o Supremo Tribunal Federal - STF (RE n. 466.343-1/SP) é assente no sentido de que o Tratado em questão goza de status de norma supralegal, situando-se em posição hierárquica inferior à Constituição Federal, porém, superior a toda legislação infraconstitucional.

${ }^{14}$ Por exceção, a jurisdição do Tribunal Penal Internacional também incidirá sobre os crimes contra a administração de sua justiça, conforme prevê o artigo 70 do Estatuto de Roma (Decreto n.․․ 4.388/02).

15 Incidência do Princípio da Complementariedade (ou da Subsidiariedade) sobre o qual assenta a atuação do Tribunal Penal Internacional no tocante ao exercício de sua jurisdição.
} 


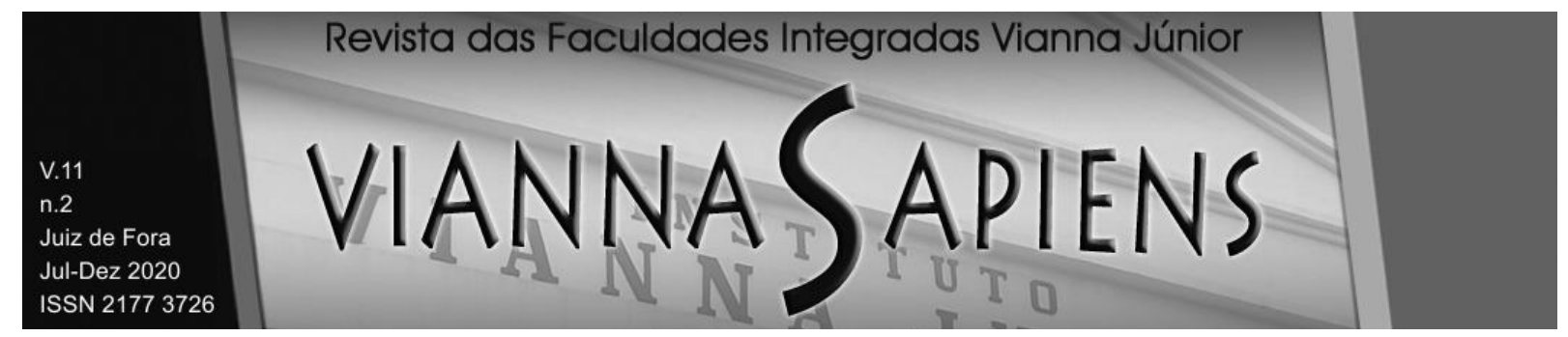

Esta velocidade, portanto, conforme preleciona Pastor (2005), se concretiza através da influência neopunitivista, compreendida como conceito político-criminal caracterizado pela crença de que o poder punitivo pode e deve chegar a todos os espaços da vida social. Assim, o Direito Penal de quarta velocidade constitui o modelo de sistema penal utilizado pelo Tribunal Penal Internacional (TPI), ora competente para julgamento dos crimes de lesa humanidade praticados por líderes de Estado na esfera internacional.

Lado outro, apesar de existir um ponto em comum, não há que se confundir direito penal de quarta velocidade com o que considera, nas lições de Jakobs, como direito penal do inimigo, visto que, neste último, enxerga-se uma estrita relação com a chamada terceira velocidade, outrora analisada. Nessa toada, tem-se, diferentes concepções sobre a definição de "inimigo" ${ }^{16}$ em ambas as fases.

Portanto, a quarta velocidade está ligada a um estilo de Direito Penal absoluto e ainda mais arbitrário, revestido pelo recrudescimento sancionador somado a uma máxima celeridade na aplicação das penas no âmbito do Direito Penal Internacional ${ }^{17}$, cujas regras se sobrepõem ao sistema garantista interno.

\subsection{Direito Penal de quinta velocidade}

Na sequência das teorias sobre as velocidades do Direito Penal, enxerga-se um novo panorama social calcado no progresso de elementos tecnológicos e culturais, proveniente das ricas mutações da sociedade contemporânea, da qual insurgem novos riscos sociais e perigos dispostos na era pós-industrial. Diante da morosidade do sistema penal atual, no que concerne à efetividade da justiça no campo das infrações penais, é possível verificar uma lacuna existente entre a

\footnotetext{
16 "Para o Direito Penal do inimigo e Direito Penal de terceira velocidade, o inimigo (réu no âmbito do Direito Penal interno) é aquele que perdeu a condição de cidadão por ter deixado de cumprir sua função no corpo social (não satisfez as mínimas expectativas normativas), ao passo que, para o Neopunitivismo, o inimigo (réu na esfera do Direito Penal internacional) é aquele que alguma vez foi detentor do poder estatal e violou direitos humanos. " (GARCIA, 2015, p. 38)

${ }_{17}$ Consubstanciado a partir dos seguintes instrumentos: imprescritibilidade dos crimes de sua competência (art. 29), previsão de pena de prisão perpétua (art. 77, "b") e existência da figura do "ato de entrega" (art. 89).
} 


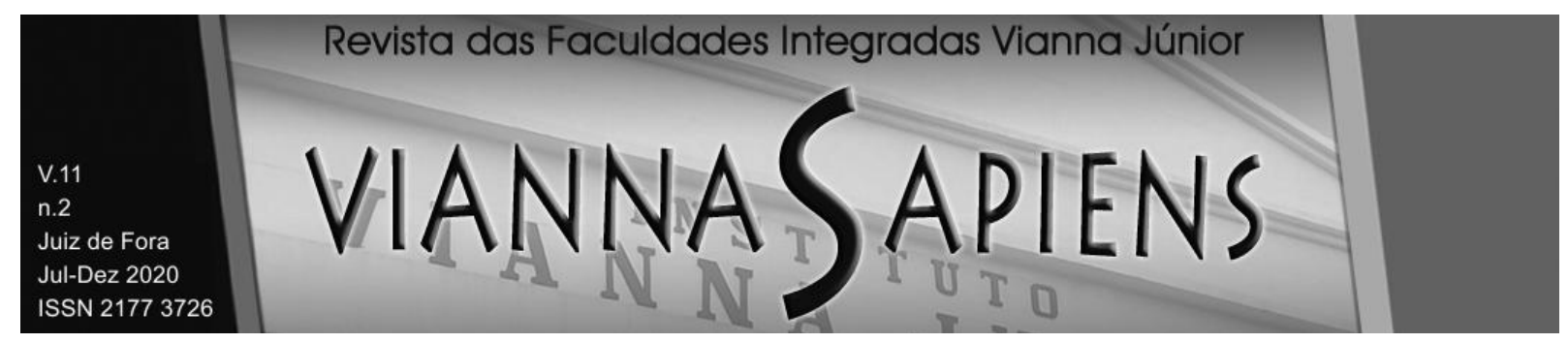

criminalidade das ruas e a resposta penal final. Nesse aspecto, mister se faz definir a atuação dos organismos policiais na sociedade do risco, haja vista ser quem, em um primeiro momento, aplicam a "justiça penal" de forma imediata.

Surge aqui o Direito Penal de quinta velocidade, teoria desenvolvida pelo jurista brasileiro, Walmir Messias de Moura Fé (A Expansão Policial), inspirado na expansão das funções dos órgãos policiais, voltadas à prevenção dos novos riscos existentes na sociedade moderna. Corolário da demanda pela fiscalização e controle social, atualmente as agências policiais têm recebido uma vasta gama de atribuições para a gerência das complexidades presentes nas mais variadas relações da vida cotidiana. Assim, segundo Fé (2012, p. 159):

Há uma busca frenética da população por policiamento, contenção de riscos, prevenção de perigos, diálogo sobre ilícitos civis e administrativos, combate de enfrentamento contra traficantes de drogas e assaltantes de bancos, vigilância em grandes eventos, prisão imediata de delinquentes contumazes, rigor na lei e ordem, desobstrução de delinquentes habituais dos centros das cidades, neutralização dos irrecuperáveis e psicopatas, atuação na fiscalização do cumprimento de penas em todos os regimes, inclusive, de menores infratores, assunção de tarefas da execução penal, maior atuação em políticas públicas, mormente, opinando sobre edificações, saúde, trânsito e multas, maior aproximação do Judiciário quanto à eficácia das medidas cautelares e prisões definitivas.

Nessa linha de raciocínio, torna-se imperiosa uma imediata atuação da justiça penal, com vistas a concretizar os bens e direitos essenciais para o ser humano, como a vida, saúde, integridade física, patrimônio, meio ambiente, educação e a própria segurança, o que, em primeiro plano, só é possível através da ação dos órgãos policiais. Logo, de acordo com Fé (2012), a ação momentânea desse moderno Direito Penal está fundamentada na finalidade de prevenção das mazelas e consequências danosas às pessoas, já que numa sociedade eivada pelo caos, exige-se um Poder de Polícia mais adequado à mobilidade social no contexto de riscos e perigos constantes. 


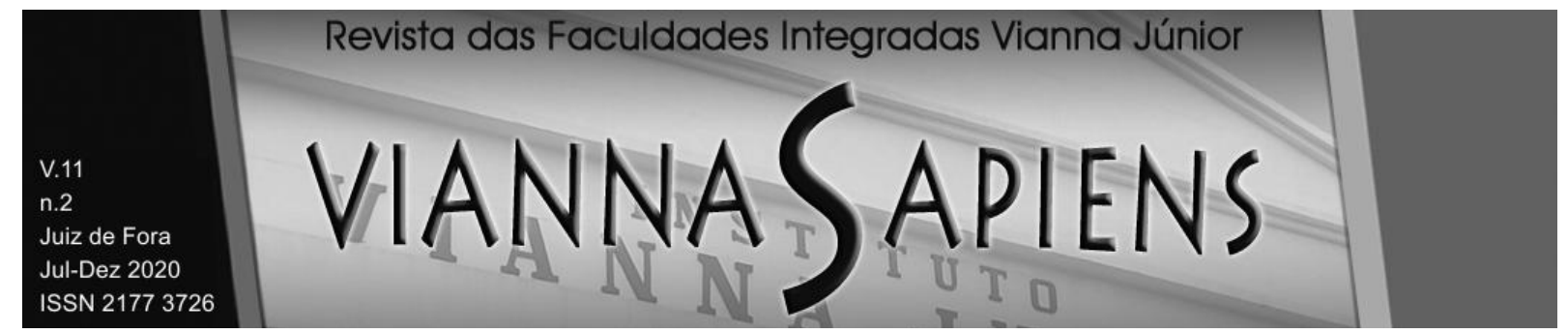

De fato, atualmente tem-se a Polícia como abalizadora imediata das contendas penais. Contudo, não se pode confundir neste modelo de Direito Penal de quinta velocidade (diga-se de passagem "Direito Penal de Polícia") com o que se denomina "Estado Policial", revestido na ideia de um intenso controle estatal da sociedade através do uso da força e da repressão política, com extremada ingerência nas liberdades públicas. Opera-se, assim, um novo arquétipo de Direito Penal mais presente nos variados setores da vida social onde a criminalidade, por sua vez, expande seu campo de incidência.

Dessa forma, a escalada da criminalidade no cenário atual resvala na configuração de um sistema penal mais adequado para uma rápida concretização da justiça, objetivando a manutenção da paz social. Isso porque, "[...] diante da morosidade e ineficácia do processo penal, a população tende a acreditar na ação imediata da Polícia, que tem a possibilidade de concretizar rapidamente a justiça no campo das infrações penais [...]" (FÉ, 2012, p. 24) ${ }^{18}$. Nesse seguimento, resta consolidado a quinta velocidade do Direito Penal, onde se impõe uma maior assiduidade do controle policial, ante a deficiência teórica na resposta concreta inferida pela dogmática penal clássica.

\section{CONSIDERAÇÕES SOBRE O ATUAL SISTEMA PUNITIVO: TENDÊNCIAS DE DIREITO PENAL PARA O FUTURO E O “FETICHISMO" PELAS VELOCIDADES}

Hodiernamente, o aumento do arsenal punitivo do Estado para o enfrentamento dos novos riscos vem se tornando uma tendência na sociedade moderna. É quase inevitável que, com o passar do tempo, novos ritmos de ação punitiva estatal sejam propostos com 0 fito de se adequarem às constantes mudanças sociais, por meio de uma afeição generalizada pela inflação de normas

\footnotetext{
${ }^{18}$ Uma demonstração clara dessa velocidade no cenário atual seriam as propostas do governador do estado do Rio de Janeiro, Wilson Witzel, sobre a utilização de drones e snipers - atiradores de elite em ações contra o crime organizado, autorizando o abatimento de criminosos que portarem armas de uso exclusivo das forças armadas. (Para maiores informações, acessar: <https://g1.globo.com>)
} 


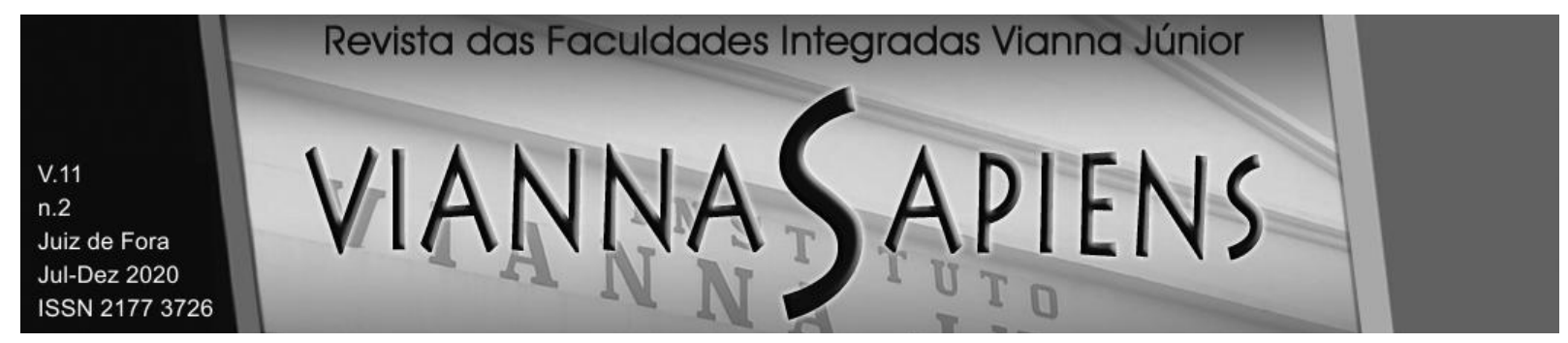

punitivas em geral. Nesse aspecto, o fenômeno denominado "avanço expansionista" apresenta-se de grande influência na sistemática jurídica contemporânea, exigindo a presença do Direito Penal nos mais diversificados setores da sociedade como meio de controle da nova criminalidade, em face do descrédito de outras instâncias de proteção ${ }^{19}$.

Os novos problemas socais urgem pela necessidade de se ater às novas percepções acerca de determinados bens jurídicos preexistentes ${ }^{20}$ que realçam a sensação de insegurança ventilada pela sociedade do risco. Por conseguinte, as decisões político-criminais têm concentrado seus esforços em uma maior abrangência de normas punitivas com enfoque no recrudescimento do instrumento sancionador. Opera-se, assim, uma transformação no tocante ao conceito de bem jurídico, que agora deixa de ser empregado como critério de limitação da intervenção punitiva do Estado para legitimar a criação de novas normas penais incriminadoras. Machado (2005, p. 159), em sua obra "Sociedade do Risco e Direito Penal", no que tange à concepção sobre bem jurídico, salienta que:

De um modo geral, aponta-se uma inversão nos critérios de utilização do conceito de bem jurídico: se, desde a sua concepção, esse conceito teve a função crítica de operar como limitador da intervenção punitiva do legislador e serviu de instrumental para os movimentos de descriminalização, com a pressão das novas demandas de tutela, a noção do bem jurídico vê-se transformada em critério para a exigência de intervenção penal. Ou seja, assume o papel de propulsora a ampliação e não da limitação do ius puniendi. Por isso se diz que, ao lado da progressiva expansão do significado do conceito de bem jurídico, há um paulatino desvanecimento de sua função garantidora dos limites ou das condições de justificação da proibição penal.

\footnotetext{
${ }^{19}$ Sob essas observações, convém destacar o "fetichismo" dos doutrinadores em querer inaugurar, constantemente, uma nova velocidade para a análise do Direito Penal, como se fosse a forma determinante para solucionar esse impasse.

20 "Por outro lado, deve aludir-se a deterioração de realidades tradicionalmente abundantes que em nossos dias começam a manifestar-se como "bens escassos", aos quais se atribui agora um valor que anteriormente não lhes correspondia, ao menos de modo expresso; como por exemplo, o meio ambiente." (SANCHEZ, 2013, p. 33)
} 


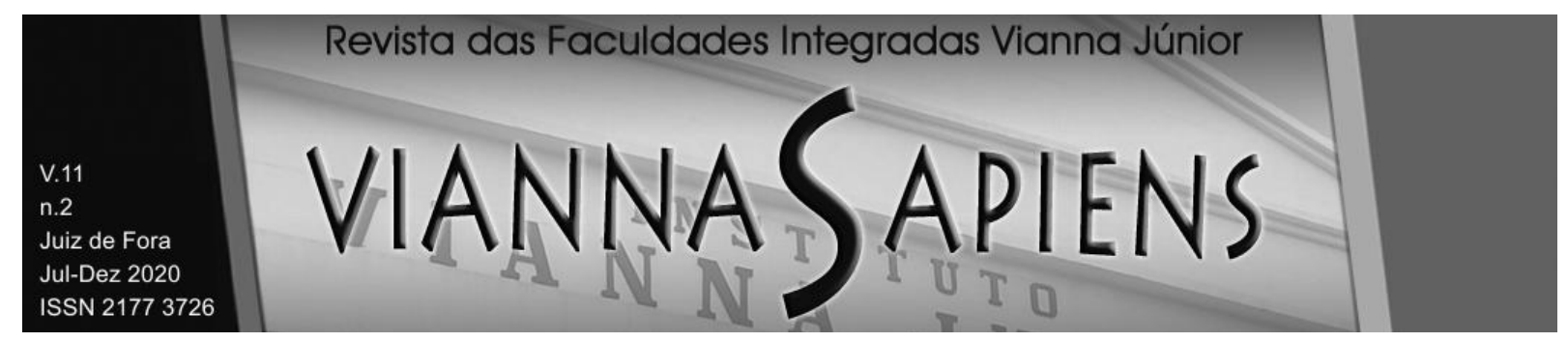

Em uma abordagem mais profunda, no tocante ao Direito Penal de quarta velocidade, tem-se que as organizações não governamentais (ONG's) que estão ligadas aos Direitos Humanos sempre clamaram pela observância aos direitos de todo e qualquer tipo de réu, mas agora são as primeiras a sustentarem a diminuição das garantias para aquele que viola tratados internacionais de Direitos Humanos. Comungando do mesmo entendimento, Pastor (2015, p. 104) preleciona:

Esta desconfortável situação foi alcançada porque as organizações de defesa dos direitos humanos - públicas, semi-públicas ou privadas - e os organismos internacionais de proteção dos direitos fundamentais têm seguido a tendência neopunitivista. Nascidos e estabelecidos para proteger neste âmbito o indivíduo que enfrenta o poder penal, nos últimos tempos têm se transformado nos principais condutores para a aplicação do direito penal aos indivíduos. Isso contribui para o descrédito do discurso dos direitos humanos, para dascreditá-los, visto que parecem o último engano do Ocidente no qual constitui uma catástrofe cultural, pois resta evidente que, em matéria penal, não se pode servir, como já mencionado, a dois objetivos ao mesmo tempo, de modo que resta impossível atender simultaneamente aos interesses punitivos (da vítima) e aos direitos fundamentais (do imputado). A formulação de uma teoria dos direitos fundamentais frente ao poder penal não admite esta bipolaridade, porquanto, ora o interesse é colocado permanentemente ao lado do indivíduo acusado, ora é feito para sempre no interesse da punição. (Tradução nossa ${ }^{21}$ )

O fato é que, a partir dessa vaga sensação de insegurança presente na sociedade de "riscos", decorre a real insegurança jurídica, deflagrando um perigoso controle penal exacerbado com desdobramentos capazes de representar ameaças

\footnotetext{
21 "A esta incómoda situación se ha llegado porque las organizaciones defensoras de los derechos humanos - públicas, semipúblicas o privadas- y los organismos internacionales de protección de los derechos fundamentales han seguido la deriva neopunitivista. Nacidas y establecidos para proteger en este ámbito al individuo enfrentado al poder penal, se han transformado en los últimos tiempos en los principales impulsores de la aplicación del derecho penal a los individuos. Esto contribuye al desprestigio del discurso de los derechos humanos, a desacreditarlos dado que parecen el último engaño de Occidente, lo cual constituye una catástrofe cultural, pues resulta evidente que, en materia penal, no se puede servir, como ya se mencionó, a dos objetivos al mismo tiempo, de modo que resulta imposible atender a la vez a los intereses punitivos (o de la víctima) y a los de los derechos fundamentales (o del imputado). La formulación de una teoría de los derechos fundamentales frente al poder penal no admite esta bipola dad debido a que, o bien se recuesta el interés permanentemente sobre el lado del individuo acusado, o bien se lo hace para siempre en interés del castigo."
} 


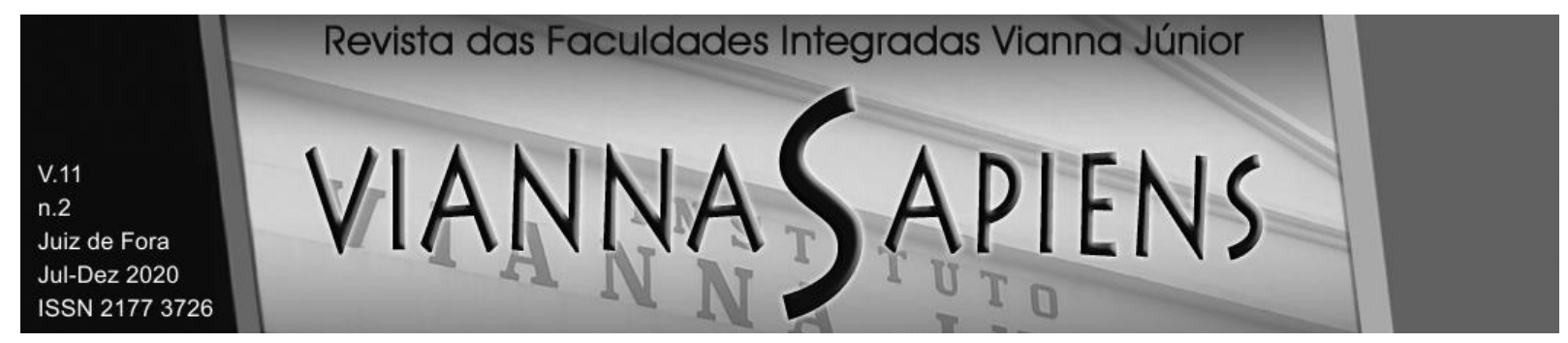

ao modelo vigente no Brasil. Chega-se a uma fase onde o Estado, se vendo em uma posição acuada, está a assumir uma feição nitidamente punitivista para atender às expectativas da sociedade do risco, através da imposição de metas irracionais fundadas em funestas proposições satisfativas e simbólicas. Sendo assim, a tão almejada efetividade que se procura através de uma legislação penal de tão elevada euforia que vise paulatinamente a antecipação da tutela penal, muitas vezes pode ser a mola propulsora para o cometimento de inúmeras injustiças no âmbito da esfera criminal.

Avançando com o tema, é de se observar que o fenômeno expansionista repulsa na formulação de novas tendências punitivistas tachadas como "velocidades", que, por seu turno, caminham em direção a uma espécie de fetichismo suscitado pelo simbolismo penal, redundando na progressiva redução das garantias político-criminais do Direito Penal desprestigiada pela carência de proteção desses novos interesses. Vislumbra-se, nesse sentido, um constante retrocesso no âmbito da Política Criminal, cujas propostas de estratégia e controle têm se baseado exclusivamente no incremento da pena em prejuízo da liberdade, o que destoa do sufrágio de se valorizar o convívio em sociedade, já que, ao julgar ineficaz um processo penal consagrado por meio de conceitos clássicos enraizados ao longo da história que pregam pela observância das garantias fundamentais, dáse azo a uma latente arbitrariedade e consequente violação às disposições que remetem a importantes postulados que constituem o pilar do ordenamento jurídico pátrio.

Rememorando os dizeres do jurista Walmir Messias de Moura Fé, no que se refere ao "Direito Penal de quinta velocidade", o autor advertiu que não se trata da implementação de um "Estado Policial"22. Ocorre que não há como mensurar os limites de uma resposta estatal que tende a se aventurar acompanhando as

22 "O Direito Policial Penal - a expansão policial - não vieram, como faz parecer a doutrina "garantista", com a proposta de gerência dos problemas sociais, com a aceitação do Estado Policial, responsável pela constante vigilância das liberdades públicas. Trata-se, sim, na verdade, de garantir as liberdades e os direitos humanos dos cidadãos, nos quais o Direito Policial estará, queira-se ou não, presente em todas as camadas sociais, já que o crime, decorrente de negligência, ocorre em todos os setores da vida, como em construções imobiliárias, engenharia genética, venda de produtos com dano à saúde pública, danos ambientais, engenharia atômica, dentre outros." (FÉ, 2012, p. 193) 


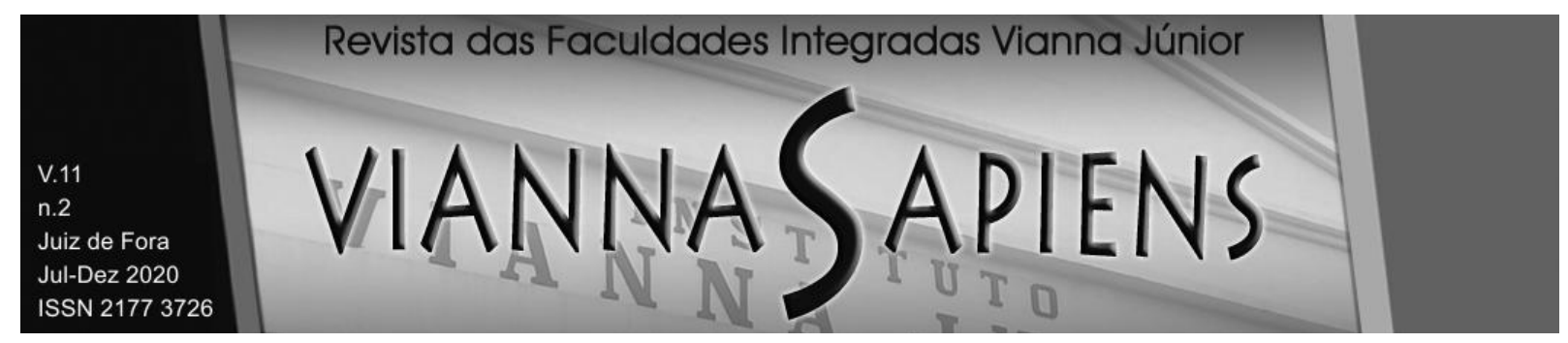

demandas de criminalização, fruto de incessantes transformações sociais, fazendose oportuna uma maior reflexão sobre a atuação dos organismos policiais sob a égide dessa perene expansão.

Nesse contexto, é forçoso concluir que em um dado momento haveria o risco deste campo de atuação ampliar-se sobremaneira a ponto de repercutir diretamente no bem-estar individual. Isso, inclusive, é o que se tem percebido por meio de uma verificação do próprio cenário atual através da implantação das Unidades de Polícia Pacificadora (UPP's) no complexo das favelas do Rio de Janeiro/RJ onde, não rara as vezes, tem-se constatado casos de abusos policiais nas comunidades e protestos contra a ocupação policial ${ }^{23}$. Ademais, insta salientar que o decreto pela Intervenção Federal no estado do Rio de Janeiro, assim como as operações de Garantia da Lei e da Ordem (GLO) para reforçar o combate ao crime organizado diante da crise na segurança pública, reafirmam o fracasso das ações interventoras, que deflagraram o aumento dos índices de violência em diversas localidades do estado, com uma sequência de crimes e mortes numa proporção histórica (em especial, de moradores e agentes de segurança), onde se percebe o agravo do quadro de violência diária, além de meros resultados pífios. ${ }^{24}$

De outro importe, caminhar sob a direção de uma justiça interventora destinada a atuar de forma extremamente repressiva, fundada na ideologia do maximalismo penal, não parece condizente com o caráter subsidiário e fragmentário por meio do qual se reveste o Direito Penal. Diga-se aqui "subsidiário" não apenas em relação a outros ramos do direito, mas também no que se refere ao sistema de controle social da criminalidade como um todo. Em vista disso, vale lembrar que o Princípio da Intervenção Mínima deve desempenhar um papel importante como norteador da dogmática penal, restringindo a ingerência punitiva estatal até o mínimo indispensável para uma razoável racionalidade penal.

${ }^{23}$ Para maiores informações, ver: "O Globo" e "Carta Capital". Disponíveis em: <https://oglobo.globo.com> e <https://www.cartacapital.com.br>. Acessos em 29 out. 2018.

${ }_{24}$ Para maiores informações, ver: "Carta Capital". Disponível em: <https://www.cartacapital.com.br>. Acesso em 07 nov. 2018. 


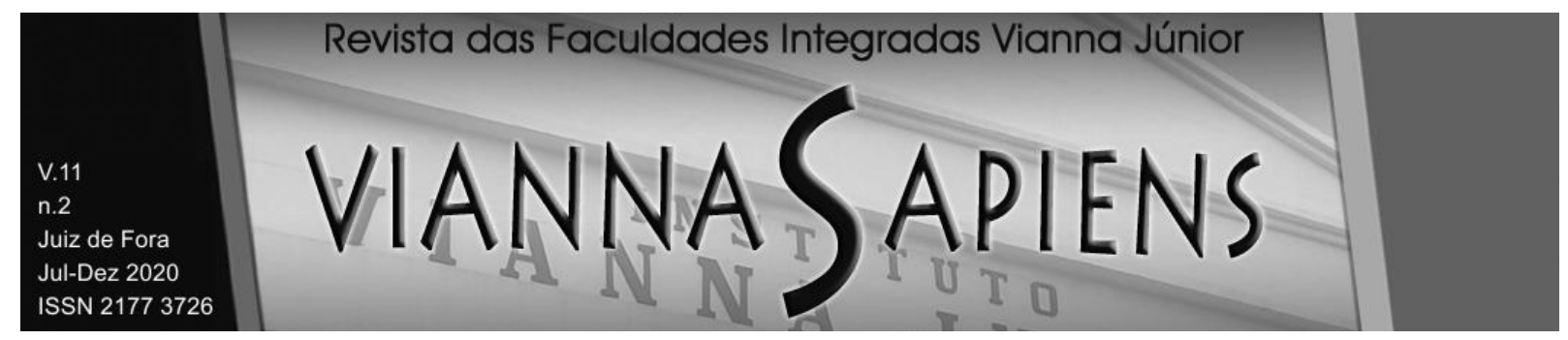

Tais situações avançam ainda ao prognóstico de um encarceramento em massa, o que não expressa qualquer utilidade para uma sociedade onde a escalada da criminalidade tem se adequado constantemente às novas estratégias de controle provenientes dessa nova configuração bélica de Política Criminal, que se eleva a uma perceptível contaminação do sistema carcerário, através de prisões superlotadas de pessoas sem condenação.

Como se vê, a análise do avanço expansionista como medida destinada a amenizar os anseios sociais de justiça, indica que os limites para a intervenção do Estado vêm sendo gradativamente excedidos. Os efeitos dessa atuação imediatista, baseada em fontes obscuras e imprevisíveis de perigos, são suficientes para demonstrar a irrazoabilidade da atuação impetuosa do Estado, que se vê paulatinamente desvencilhando de sua característica de democrático de direito. Logo, é cediço que a inauguração de novas velocidades, através desse modelo repressivo, tende legitimar a progressiva desformalização do Direito Penal, deturpando sua configuração clássica, sob o pretexto de propiciar uma atuação mais célere e de eficácia preventiva, diante do medo disseminado.

\section{CONSIDERAÇÕES FINAIS}

A aparição de novas valorações de bens jurídicos preexistentes deflagra a expansão do Direito Penal que, por sua vez, tende a um simbolismo penal que pressagia o incremento da pena como único instrumento de controle da criminalidade. Com isso, surgem as Velocidades do Direito Penal, ora tratadas no decorrer do presente trabalho, que, nesse contexto, têm figurado como o principal recurso para reagir às complexidades das causas pelas quais o Direito Penal se expande.

Com efeito, a fragilização do elemento sancionador de grande parte das leis penais deu vazão a um sentimento de impunidade que orbita ao redor da sociedade contemporânea. Não se sustenta, porém, a proposta de maior abrangência das 


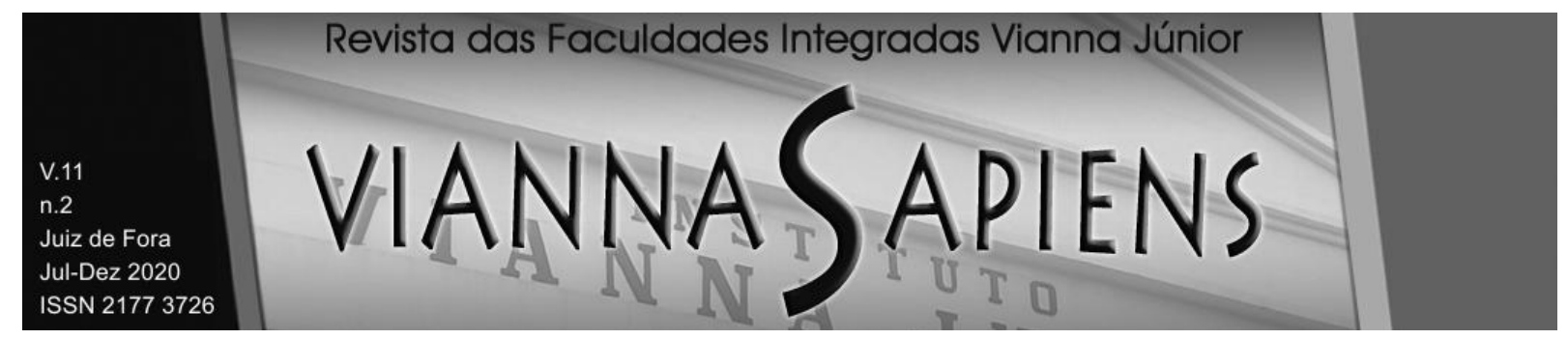

normas incriminadoras como solução para os novos problemas sociais, cujos resultados projetam imensuráveis prejuízos a longo prazo. Em outras palavras, foge ao senso geral o subterfúgio de que o Estado deva buscar a qualquer custo o controle social, na ânsia de uma rápida resposta penal, máxime mediante o incremento do aparato repressivo junto a uma evidente diminuição das garantias fundamentais.

Não se trata de fechar os olhos para os problemas presentes na sociedade; é necessário, de fato, enfrentá-los, visto que a sociedade não pode ficar à mercê da ineficiência de um sistema penal em detrimento das novas formas de criminalidade existentes. Entretanto, há que se sopesar o jus puniendi (direito de punir do Estado) com o que se denomina jus poenale (ou seja, as garantias penais consubstanciadas através das normas objetivas), de modo a impedir eventuais ações arbitrárias do Estado, decorrentes de uma expansão desarrazoada do Direito Penal.

Finalmente, não parece adequado o Direito Penal permanecer no caminho que ora percorre, onde diariamente vem sendo formulada novas tendências que optam por uma extremada intervenção punitiva, sem qualquer efetividade no cenário atual senão uma utópica sensação de bem-estar e equilíbrio social. Estar-se-á a instaurar um inexorável ciclo vicioso, no qual a ostensiva incontrolabilidade da intervenção penal reflete a destruição do próprio sistema atual.

Destarte, infere-se que as formas de reação oficiais devem se espelhar em um modelo de direito penal mais humanitário, sem que seja necessário sacrificar o sistema de direitos e garantias. Para isso, é crucial que o combate à criminalidade seja pautado pelo respeito aos fundamentos que arquitetaram o Estado Democrático de Direito, viabilizando-se, assim, a efetiva proteção do corpo social, indistintamente, sem reprimir as liberdades individuais. 


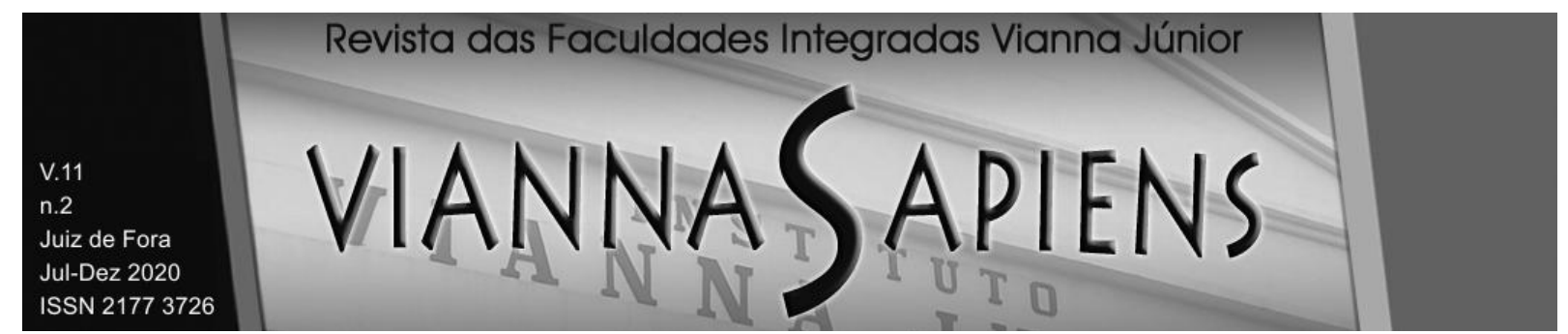

\section{REFERÊNCIAS}

BRASIL. Constituição (1988). Constituição da República Federativa do Brasil: texto constitucional promulgado em 5 de outubro de 1988. 42. ed. Brasília: Câmara dos Deputados, 2014. 110 p. (Série textos básicos; n. 85).

CUNHA, Rogério Sanches. Manual de direito penal: parte geral (arts. $1^{\circ}$ ao 120). 4 . ed. rev., ampl. e atual. Salvador: JusPODIVM, 2016. cap. 1, p. 31-41.

FÉ, Valmir Messias de Moura. A expansão policial. São Paulo: Lexia, 2012. 206 p.

GARCIA, Leonardo de Medeiros (Coord.). Direito penal: parte geral. 5. ed. rev., ampl. e atual. Salvador: JusPODIVM, 2015. vol. 1. cap. 1, p. 33-48.

JAKOBS, G.; MELIÁ, M. C. Direito Penal do inimigo: noções e críticas. org. e trad. André Luís Callegari, Nereu José Giacomolli. ed. Porto Alegre: Livraria do Advogado, 2005. $118 \mathrm{p}$.

MACHADO, Marta Rodriguez de Assis. Sociedade do risco e direito penal: uma avaliação de novas tendências político-criminais. São Paulo: IBCCRIM, 2005. 236p.

MASSON, Cleber. Direito penal esquematizado: parte geral. 11. ed. rev., atual. e ampl. São Paulo: MÉTODO, 2017. vol. 1. cap. 6, p. 99-120.

PASTOR, Daniel Roberto. La deriva neopunitivista de organismos y activistas como causa del desprestigio actual de los derechos humanos. Nueva Doctrina Penal, Buenos Aires, p. 73-114, 2005.

SÁNCHEZ, Jesús-María Silva. A expansão do direito penal: aspectos da política criminal nas sociedades pós-industriais. Trad. Luiz Otávio de Oliveira Rocha. 3. ed. rev. e atual. São Paulo: Revista dos Tribunais, 2013. 236 p. 